\title{
Biopsychosocial Factors that Interfere in the Rehabilitation of Burn Victims: Integrative Literature Review
}

\author{
Natália Gonçalves ${ }^{1}$ \\ Maria Elena Echevarría-Guanilo² \\ Fernanda de Loureiro de Carvalho ${ }^{3}$ \\ Adriana Inocenti Miasso ${ }^{4}$ \\ Lidia Aparecida Rossi ${ }^{5}$
}

\begin{abstract}
This study aimed to identify the biopsychosocial factors that influence the rehabilitation of burn victims, through an integrative literature review, from January 1987 to January 2007. Articles were searched in databases Scielo, Pubmed and Lilacs, resulting in 982 articles, of which 45 were selected, after the analysis and categorization processes. Most studies were descriptive and qualitative. The most frequently associated factors to the rehabilitation process were: mental health state before the accident, coping strategies and family support, besides the severity of the burn and the total body surface area burned. The quality of the selected studies, most classified as evidence level VI, shows the scarce production of strong evidences in this knowledge area, which needs more investment, considering the important implications of the sequelae of burns in the social reintegration of these people.
\end{abstract}

Descriptors: Rehabilitation; Burns; Social Support.

\footnotetext{
${ }^{1}$ Nursing undergraduate student, Escola de Enfermagem de Ribeirão Preto, Universidade de São Paulo, WHO Collaborating Centre for Nursing Research Development, SP, Brazil. Scholarship holder of the Scientific Initiation Program at the Conselho Nacional de Desenvolvimento Científico e Tecnológico (CNPq). E-mail: nataliasjbv@hotmail.com.

2 RN, Ph.D. in Nursing. Adjunct Professor, Faculdade de Enfermagem, Universidade Federal de Pelotas, RS, Brazil. E-mail: bbpino@hotmail.com.

${ }_{3}^{3}$ Psychologist, Doctoral Student, Escola de Enfermagem de Ribeirão Preto, Universidade de São Paulo, WHO Collaborating Centre for Nursing Research Development, SP, Brazil. E-mail: fer.lc@bol.com.br.

${ }^{4}$ RN, Ph.D. in Nursing. Professor, Escola de Enfermagem de Ribeirão Preto, Universidade de São Paulo, WHO Collaborating Centre for Nursing Research Development, SP, Brazil. E-mail: amiasso@eerp.usp.br.

${ }^{5}$ RN, Ph.D. in Nursing. Full Professor, Escola de Enfermagem de Ribeirão Preto, Universidade de São Paulo, WHO Collaborating Centre for Nursing Research Development, SP, Brazil. E-mail: rizzardo@eerp.usp.br.
}

Corresponding Author: Lídia Aparecida Rossi Universidade de São Paulo. Escola de Enfermagem de Ribeirão Preto Departamento de Enfermagem Geral e Especializada

Av. dos Bandeirantes, 3900

Bairro: Monte Alegre

CEP: 14040-902 Ribeirão Preto, SP, Brasil

E-mail: rizzardo@eerp.usp.br 


\title{
Fatores biopsicossociais que interferem na reabilitação de vítimas de queimaduras: revisão integrativa da literatura
}

Este estudo teve como objetivo identificar os fatores biopsicossociais que influenciam a reabilitação de vítimas de queimadura, por meio de revisão integrativa de literatura, no período de janeiro de 1987 a janeiro de 2007. A partir da busca dos artigos nas bases de dados SciELO, PubMed e LILACS, obtiveram-se 982 artigos, dos quais 45 foram selecionados. A maior parte dos estudos era do tipo descritivo e qualitativo. Os fatores mais frequentemente associados ao processo de reabilitação foram: estado de saúde mental prévio ao acidente, estratégias de enfrentamento e apoio da família, além da gravidade da queimadura e da superfície corporal queimada. A qualidade dos estudos, na maioria classificados com nível de evidência VI, chama a atenção para a escassa produção de evidências fortes nessa área do conhecimento, necessitando maiores investimentos, considerando-se as importantes implicações das sequelas da queimadura na reintegração social dessas pessoas.

Descritores: Reabilitação; Queimaduras; Apoio Social.

\section{Factores biopsicosociales que interfieren en la rehabilitación de víctimas de quemaduras: revisión integradora de la literatura}

\begin{abstract}
Este estudio tuvo como objetivo identificar los factores biopsicosociales que influyen en la rehabilitación de víctimas de quemaduras, por medio de una revisión integradora de la literatura, en el período de enero de 1.987 a enero de 2.007. A partir de la búsqueda de los artículos en las bases de datos Scielo, Pubmed y Lilacs, se obtuvieron 982 artículos, de los cuales 45 fueron seleccionados. La mayor parte de los estudios era de tipo descriptivo y cualitativo. Los factores más frecuentemente asociados al proceso de rehabilitación fueron: estado de salud mental previo al accidente, estrategias de enfrentamiento y apoyo de la familia, además de la gravedad de la quemadura y de la superficie corporal quemada. La calidad de los estudios, en la mayoría clasificados con nivel de evidencia VI, Ilaman la atención para la escasa producción de evidencias fuertes en esta área del conocimiento, que necesita mayores inversiones, considerando las importantes implicaciones de las secuelas de la quemadura en la reintegración social de esas personas.
\end{abstract}

Descriptores: Rehabilitación; Quemaduras; Apoyo Social.

\section{Introduction}

Thousands of people suffer the physical, psychological and social consequences a burn causes, which can continue over time or be permanent ${ }^{(1)}$.

The biological factors the burn affects need to be treated and managed with a view to the burn victim's adaptation after discharge from hospital. It should not be forgotten, however, that we live in a dynamic and sociable environment, where we influence and are influenced by other people's behavior.

Rehabilitation, defined as a process that serves to enable people to maintain or reach satisfactory intellectual, sensory, physical, psychological and social health levels, should offer tools to re-enable them to gain independence and reassume their role in society ${ }^{(2)}$. Health professionals play a fundamental role in supporting burn victims' adaptation(2), keeping in mind their maximum existing capacity, instead of just focusing on the disability. The interdisciplinary team should work with the principles of the rehabilitation philosophy, which are independence, integration, sense of justice, equality and equity and people's inclusion(2). 
Literature shows that the total body surface area (TBSA) burned, age, gender, ethnic origin, burn depth, injury site and pain can predispose to bad physical, social and psychological rehabilitation and worsening of the general health condition ${ }^{(3-6)}$. The burn, mainly in exposed body parts, provokes decreased self-esteem and turbulent emotions. Burns victims feel exposed due to the skin injury, which exposes them to pathogens, deformations, fluid loss and risk of death, as well as due to the feeling of powerlessness and guilt for the accident ${ }^{(7-8)}$. The following have been described as feelings associated with burn trauma: anguish, stress, fear, anxiety, which can hamper coping with the situation, that is, rehabilitation ${ }^{(9-12)}$.

After hospital discharge, survivors of severe burns start to experience a chronic condition that demands permanent care, mainly skin care. This study aimed to identify, through an integrative literature review, biopsychosocial factors interfering in the rehabilitation of burns victims.

\section{Theoretical-methodological framework}

The integrative literature review is an important method for evidence-based practice, as it permits analyzing various studies with different (quantitative and qualitative) methods in the same research, as well as to join trials and theoretical studies, constructing a new conception on a given topic. Nursing professionals frequently use this method, as it is strongly related with evidence-based practice, and mainly with patient care improvements(13). Evidence can be ranked, depending on the methodological approach used in the studies ${ }^{(14)}$. In this review, the following evidence level ranking was used: I - evidence from systematic review or metaanalysis of all randomized controlled clinical trials or deriving from clinical guidelines based on systematic review of randomized controlled clinical trials; IIevidences deriving from at least one well-designed randomized controlled clinical trial; III- evidence obtained from well-designed clinical trials without randomization; IV - evidence from well-designed cohort and casecontrol studies; $V$ - evidence from a systematic review of descriptive and qualitative research; VI - evidence from a single descriptive or qualitative study; VII evidence based on authoritative opinions and/or expert committee reports ${ }^{(15)}$.

The development of this integrative review involved the following phases: 1 . establishment of guiding question; 2 . selection of articles and inclusion criteria; 3. extraction of articles included in the Integrative Review; 4. assessment of studies included in the Integrative
Review; 5. interpretations of Results and; 6. presentation of Integrative Review(13).

With a view to answering the guiding question: "What biopsychosocial factors interfere in the rehabilitation process of burns victims?", a search was carried out in Pubmed, LILACS and Scielo, between October 2007 and January 2008. The following controlled descriptors were defined: rehabilitation, burns, culture and social support, as well as the noncontrolled descriptors: psychological, biopsychosocial rehabilitation and social. The search limits were: humans, adults and publication period from 1987 to 2007. Also, the inclusion criteria were: complete studies related to rehabilitation themes in the biological, psychological and sociocultural spheres, and papers in English, Portuguese and Spanish.

In PubMed, 905 papers were located, 79 of which were selected. For Scielo, the descriptors were defined as "key words" and "abstract", resulting in 54 papers, 10 of which were selected. In LILACS, 23 papers were located, four of which were included. After analyzing the full texts of all articles under analysis, in view of inclusion criteria and repetitions, 48 papers were excluded. In the final sample, 45 articles were obtained. One of the researchers selected the papers and received confirmation from two others.

To rank and facilitate analysis of the papers, an instrument was adapted from literature ${ }^{(16-17)}$, which two researchers experienced in this type of review and in the theme area assessed for content adequacy.

The analysis of the study designs included in this integrative review was based on concepts presented in literature ${ }^{(18-19)}$, which classifies them as studies with a quantitative approach (experimental, quasi-experimental and non-experimental design), qualitative approach (ethnographic, phenomenology, grounded theory, case study, biography, narrative analysis, history, metasynthesis) and reviews (integrative, systematic and literature) $)^{(18-19)}$.

The analysis process attempted to identify the biopsychosocial factors associated with the rehabilitation process, resulting in the identification of three categories: 1- Factors related with social and emotional support, 2- Psychological factors and 3- Factors associated with burn trauma and severity.

\section{Results}

The final sample included 45 papers (four from Lilacs, three from Scielo and 39 from Pubmed). Fortyone papers were classified as evidence level VI (non- 
experimental and qualitative); three as level VII (expert opinion); and one as level $\mathrm{V}$ (systematic review). Numbers were used to refer to the papers included in this review: 3 and 4; 6 to 12 and 20 to 55 .

Next, the three identified categories are presented.

\section{Factors related with social and emotional support}

The factors associated with this group were identified in 20 papers, 18 of which were classified as evidence level VI.

According to two studies with a correlation design (evidence level VI), emotional support is associated with better rehabilitation and quality of life ${ }^{(37-38)}$ but, at the same time, one study mentions that living alone is related with better integration in domestic and social activities, as burns victims would perform their activities independently(39).

\section{Psychological factors}

These factors were found in 22 papers and organized in three sub-categories: factors related with mental health condition and individual characteristics before the accident; related with treatment experience and with post-trauma adaptation mechanisms. Factors related with mental health condition and individual characteristics before the accident include aspects related to negative experiences before the accident, drugs abuse, organic brain syndromes, psychological development, coping strategies and self-esteem (Figure 2).

\begin{tabular}{|c|c|}
\hline Evidence Level & Factors related with social and emotional support \\
\hline $\mathrm{E}-\mathrm{VI}$ & $\begin{array}{l}\text { Team support }{ }^{(12,20-21)} \text {, family }{ }^{(7,12,20,22-24)} \text {, friends }{ }^{(7,20,22)} \text {, significant relationships }{ }^{(9,24-27)} \text {; } \text { religion }^{(23)} \text {; } \text { spirituality }^{(7,20,28)}, \text { psychological }^{(29-1}{ }^{(26,31-33)} \text {; economic }{ }^{(27,34)}\end{array}$ \\
\hline E-VII & family(35-36); friends ${ }^{(35)}$ \\
\hline
\end{tabular}

Figure 1 - Distribution of papers according to evidence level and factors associated with social and emotional support

\begin{tabular}{|c|c|}
\hline $\begin{array}{c}\text { Evidence } \\
\text { Level }\end{array}$ & Factors related with mental health condition and individual characteristics before the accident \\
\hline $\mathrm{E}-\mathrm{V}$ & Mental health condition before the accident ${ }^{(40)}$; coping strategies ${ }^{(40)}$ \\
\hline E-VI & $\begin{array}{l}\text { Mental health condition before the accident }{ }^{(24-25,27,34,37,41-42)} \text {; previous negative experiences }{ }^{(31,43)} \text {; drugs abuse }{ }^{(25-26)} \text {; previous organic brain } \\
\text { syndromes }^{(25)} ; \text { psychological development }{ }^{(25,30)} \text {; coping strategies }(7,9,12,25,28,30-31,44) \text {; self-esteem }(8,32)\end{array}$ \\
\hline E-VII & 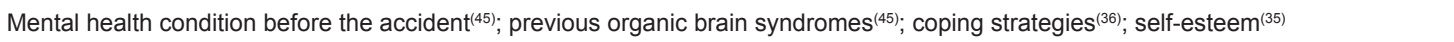 \\
\hline
\end{tabular}

Figure 2 - Distribution of papers according to evidence level and factors related with mental health condition and individual characteristics before the accident

The results of some descriptive correlation studies show a statistically significant association between worse mental health condition before the accident and impaired psychosocial adaptation in the rehabilitation phase ${ }^{(24,37,41)}$. Factors related with the treatment experience, including painful procedures experienced while in hospital, involvement in self-care and unreal expectations in the rehabilitation phase, are shown in Figure 3 and were mentioned in four studies.

\begin{tabular}{|l|l|}
\hline \multicolumn{1}{|c|}{ Evidence Level } & \multicolumn{1}{c|}{ Factors related with treatment experience } \\
\hline E-VI & Meanings attributed to procedure experience during hospitalization ${ }^{(9,29)}$; self-care encouragement ${ }^{(31)}$ \\
\hline E-VII & Unreal expectations during rehabilitation ${ }^{(45)}$ \\
\hline
\end{tabular}

Figure 3 - Distribution of papers according to evidence level and factors related with treatment experience

Figure 4 displays the factors related with posttrauma adaptation mechanisms: post-traumatic stress, anguish, psychological vulnerability and feelings of threat, anxiety, dissatisfaction with body image and depression. These factors were appointed as associated with the rehabilitation process in 14 studies. 


\begin{tabular}{|l|l|}
\hline \multicolumn{1}{|c|}{ Evidence Level } & \multicolumn{1}{c|}{ Factors related with post-trauma adaptation mechanisms } \\
\hline E-V & Depression $^{(40)}$ \\
\hline E-VI & $\begin{array}{l}\text { Post-traumatic stress } \\
\text { with body image }{ }^{(48-10,40)} ; \text { depressão }^{(25,34)}\end{array}$ \\
\hline E-VII & Post-traumatic stress ${ }^{(45)}$ \\
\hline
\end{tabular}

Figure 4 - Distribution of papers according to evidence level and factors related with post-trauma adaptation mechanisms

\section{Factors related with burn trauma and severity}

Regarding the factors related with the burn trauma and severity, 31 papers were identified, shown in Figure 5.

\begin{tabular}{|c|c|}
\hline Evidence Level & Factors related with burn trauma and severity \\
\hline $\mathrm{E}-\mathrm{V}$ & Burn location ${ }^{(40)}$ \\
\hline E-VI & 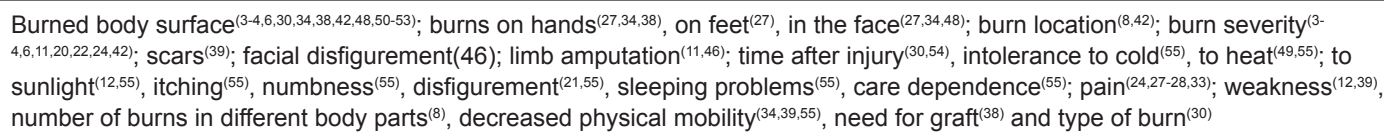 \\
\hline E-VII & Hand burns ${ }^{(35)} ;$ scars $^{(36)} ;$ pain $^{(45)}$ \\
\hline
\end{tabular}

Figure 5 - Distribution of papers according to evidence level and factors associated with burns trauma and severity

As for the factors associated with the burn trauma and severity, greater TBSA burned was associated with worse adaptation after hospital discharge in different studies $^{(3-4,6)}$.

\section{Discussion}

It is known that the rehabilitation process of burn patients is complex, needs a multidisciplinary team, with a holistic care focus, and should aim to enhance adaptation, including physical, psychological and social recovery. Therefore, knowledge is needed about the different (internal and external) factors that can influence these people's rehabilitation. TBSA burned was appointed as a sign of worse adjustment and quality of life in some descriptive studies in this review (level VI) ${ }^{(50-}$ 53) as, the larger the TBSA burned, the greater difficulties will be to perform domestic chores, body care, mobility, social integration and, mainly, return to work. Burn severity was also appointed as a factor that hampers rehabilitation and functional recovery, as it can lead to contractures, numbness and itching skin ${ }^{(27,40,42)}$.

In this review, besides burn severity and TBSA burned, mental health status before the accident (psychiatric pre-morbidities, mood disorders, chemical addiction), ineffective coping strategies and family support (lack of support from relatives or friends) were identified as factors that are frequently associated with the rehabilitation process. It should be highlighted that greater extent of TBSA burned is associated with longer hospitalization and greater visibility of injuries. A recently published review found similar results, despite distinct inclusion criteria(56).

One of the factors that hampers the rehabilitation process is related with the patients' stress coping abilities and the strategies they use, which can be related with several other emotional, psychological or psychiatric disorders (low self-esteem, depression, trait anxiety, personality disorder, among others). As identified in a recent study ${ }^{(57)}$, not included in this review, the pre-burn mental health condition can interfere in the rehabilitation process, as it can lead to worse psychosocial adjustment and can also influence improvements in physical functions. That research, which included 64 burn patients, found that 24 had depression and post-traumatic stress after 12 months of follow-up, 20 of whom had a previous psychiatric history. It was also verified that most patients had severe depression before the injury, while only two participants did not experience any previous episode of psychiatric disorder(57). In this review, studies showed that depression was more present in patients after the burn and that greater TBSA burned and hand and face burn visibility can increase the chance of developing depression, besides being related with limitations in social and occupational activities(34). In literature, 
another study calls attention to the fact that even burn victims without previous mental health diagnoses were more vulnerable than the general population, which can be a factor that contributed to the accident ${ }^{(58)}$.

As identified in the results, previous negative experiences and patients' personality are predisposing factors regarding emotional condition in the long term. The previous identification of these problems delays possible complications during hospitalization and rehabilitation, besides helping care planning(41,53). Personality can also influence the appearance of post-traumatic stress and is related with individual coping(5). It can delay return to work $^{(39)}$ and this return, when hampered or absent, can lead to cases of post-traumatic stress ${ }^{(6)}$. Posttraumatic stress can be defined as an anxiety disorder, characterized by the occurrence of a traumatic event the person experienced or witnessed, manifesting intense feelings of fear, impotence or horror ${ }^{(59)}$. The burn is a traumatizing event since, as reported, it exposes victims to pathogens, due to the loss of skin integrity, as well as to perceptions, feelings and psychological reactions related to the fact of being burned, which victims are not always ready to cope with. The appearance of posttraumatic stress in burn patients is the main psychiatric illness. Health professionals should pay attention to identify its signs and symptoms, demanding competence, sensitivity and specialization to deal with this situation.

Besides affecting the victim, the burn affects the entire family, which should also receive attention and be included in care planning, with a view to a better return to activities for all members and to achieve better outcomes, mainly in terms of quality of life. Social support from relatives, friends and significant persons was another important factor found in this review. In a study involving relatives of burn victims, it was observed that they try to help the victim through stimuli and support, such as listening, calming down and talking, so that the person does not feel inferior; through the demonstration of feelings of love and happiness ${ }^{(7)}$. The family also takes charge of responsibilities, involving healthy members as well as care delivery for the relative with a health problem, until complete recovery is achieved. Family members experience the disease and its consequences together, entailing weakness and vulnerability, due to the disease itself as well as the financial conditions it entails(60). Support sources are maintained as a result of interpersonal relationships, culture or belief. For the patient, family members and the team, a significant relation $^{(25)}$ and the establishment of a strong bond are important to restore balance in the family dynamics ${ }^{(26)}$.
Another important support source found in the reviewed studies includes friends, community and health professionals. Relatives consider the social network, friends, community people and even health professionals as very important for patients with chronic conditions. The main contributions this support source offers are proximity, care delivery and financial help(60).

Hence, it is important to highlight that, although less studies included in this review identify it, the team is also appointed as a social and emotional support source in some level VI studies ${ }^{(23,29-30)}$ and considered an important support for the accomplishment of physical care as well as the creation of an emotionally safe place in institutions $^{(21)}$. The characteristics of this team appointed in the studies were: multifactorial and interdisciplinary work ${ }^{(35)}$; identification of previous history of interaction with significant people and patients' individual aspects, helping with rehabilitation ${ }^{(9)}$, gentle and attentive care delivery, enhancement of psychological support and greater sensitivity to identify patients' real needs ${ }^{(29)}$. Also related with the team and its activities, in this study, adequate analgesics were identified as a determining factor for rehabilitation ${ }^{(5,27-29)}$.

The pain the burn provokes was appointed in this review as a factor that hampers rehabilitation in four studies classified as evidence level VI, with three descriptive correlation designs ${ }^{(24,27,33)}$, one qualitative ${ }^{(28)}$ and one level VII study (expert opinion)(45). Caused by cell destruction in the site as well as the inflammatory reaction that stimulates nerve endings even further, pain in burn patients in frequently associated with anxiety and the performance of painful procedures. Despite the loss of nerve endings in third-degree burns and, thus, absence of pain, there are always adjunct regions where burns can be second-degree ${ }^{(61)}$. Consequently, these areas should also be handled carefully to cause as little pain as possible. Health professionals can underestimate pain, mainly in children, as neither a consensus nor effective pain assessment methods exist so far ${ }^{(61)}$. Pain treatment should take into account patients' individuality.

Hence, it is important for health professionals to perform rehabilitation programs focusing on the burn victim's individuality, considering both physical recovery and full psychosocial rehabilitation.

\section{Conclusions}

The studies analyzed in this review are mostly descriptive and, despite limitations, they show that the main factors influencing the rehabilitation process are the 
mental health condition before the accident (psychiatric pre-morbidities, mood disorders, chemical addiction), ineffective coping strategies and family support (lack of support from relatives or friends), besides the burn severity (extreme ages, TBSA burned and full thickness burns). Patients with problems related to one or more of these factors should receive appropriate follow-up. Knowledge on these factors can support intervention planning to facilitate the rehabilitation process, as well as further studies to test interventions or care models in the rehabilitation phase.

The quality of the identified research calls attention to the scarce production of strong evidence in this knowledge area, demanding further research, as burns mainly affect men of productive age and their sequelae entail important implications for these people's return to work and social reintegration.

Psychosocial rehabilitation trials are recommended with a view to testing interventions in multicenter studies, so as to expand the sample size, and producing reliable scientific evidence to improve care quality for burn victims.

\section{References}

1. World Health Organization (WHO). A WHO Plan for Burn Prevention and Care. [acesso em: 12 setembro 2008]. Disponível em: http://whqlibdoc.who.int/ publications/2008/9789241596299_eng.pdf.

2. Riggar TF, Maki DR. Handbook of Rehabilitation Counseling. New York: Spring Publishing; 2004. 377 p.

3. Tanttula K, Vuola J, Asko-Seljavaara S. Return to employment after burn. Burns. 1997;23(4):341-4.

4. Kimmo T, Jyrki V, Sirpa AS. Health status after recovery from burn injury. Burns. 1998;24(4):293-8.

5. Yu BH, Dimsdale JE. Posttraumatic stress disorder in patients with burn injuries. J Burn Care Rehabil. 1999; 20(5):426-33.

6. Dyster-Aas J, Kildal M, Willebrand M. Return to work and health-related quality of life after burn injury. J Rehabil Med. 2007 January;39(1):49-55. doi: 10.2340/16501977-0005.

7. Rossi LA. O processo de cuidar da pessoa que sofreu queimaduras: significado cultural atribuído por familiares. Rev Esc Enferm USP. 2001;35(4):336-45.

8. Silva MF, Silva MJP. A auto-estima de pacientes ambulatoriais com queimaduras. Rev Baiana Enferm. 2002;17(3):75-84.

9. Scherer ZAP, Luis MAV. Percepções e significados atribuídos pelos pacientes à vivência da queimadura. Acta Paul Enferm. 1998;11(2):64-72.
10. Fauerbach JA, Lawrence JW, Munster AM, Palombo

DA, Richter D. Prolonged adjustment difficulties among those with acute post-trauma distress following burn injury. J Behav Med. 1999;22(4):359-78.

11. Patterson DR, Ptacek JT, Cromes F, Fauerbach JA, Engrav L. The 2000 Clinical Research Award. Describing and predicting distress and satisfaction with life for burn survivors. J Burn Care Rehabil. 2000;21(6):490-8.

12. Carlucci VD, Rossi LA, Ficher AM, Ferreira E, de Carvalho EC. A experiência da queimadura na perspective do paciente. Rev Esc Enferm USP. 2007;41(1):21-8.

13. Whittemore $\mathrm{R}$, Knalf $\mathrm{K}$. The integrative review: updated methodology. JAN. 2005; 52(5):546-53.

14. Galvão CM, Sawada NO, Mendes IAC. A busca das melhores evidências. Rev EsC Enferm USP. 2003;37(4):43-50.

15. Melnyk BM, Fineout-Overholt E. Evidence-based practice in nursing \& healthcare. A guide to best practice. Philadelphia: Lippincott Williams Wilkins; 2005. 608 p.

16. Ursi ES. Prevenção de lesões de pele no perioperatório: revisão integrativa da literatura. [Dissertação de mestrado]. Ribeirão Preto (SP): Escola de Enfermagem de Ribeirão Preto, da Universidade de São Paulo; 2005. $130 \mathrm{p}$.

17. Pompeo DA. Diagnóstico de enfermagem náusea em pacientes no período pós-operatório imediato: revisão integrativa da literatura [Dissertação de mestrado]. Ribeirão Preto (SP): Escola de Enfermagem de Ribeirão Preto, da Universidade de São Paulo; 2007.

18. Lobiondo-Wood G, Haber J. Pesquisa em Enfermagem: Métodos, avaliação crítica e utilização. 4a ed. Rio de Janeiro: Guanabara-Koogan; 2001. 597 p.

19. Polit DF, Beck CT, Hungler BP. Fundamentos de Pesquisa em Enfermagem. Métodos, avaliação e utilização. $5^{\circ}$ ed. Porto Alegre: Artmed; 2004. 487 p.

20. Blalock SJ, Bunker BJ, Moore JD, Foreman N, Walsh JF. The impact of burn injury: a preliminary investigation. J Burn Care Rehabil. 1992;13(4):487-92.

21. Acton AR, Mounsey E, Gilyard C. The Burn Survivor Perspective. J Burn Care Res. 2007;28(4):615-20. doi: 10.1097/BCR.0b013E318093E4DB

22. Saffle JR, Tuohig GM, Sullivan JJ, Shelby J, Morris SE, Mone M. Return to work as a measure of outcome in adults hospitalized for acute burn treatment. J Burn Care Rehabil. 1996;17(4):353-61.

23. Williams NR, Davey M, Klock-Powell K. Rising from the ashes: stories of recovery, adaptation and resiliency in burn survivors. Soc Work Health Care. 2003;36(4):53-77. 
24. Moi AL, Wentzel-Larsen $T$, Salemark $L$, Wahl AK, Hanestad BR. Impaired generic health status but perception of good quality of life in survivors of burn injury. J Trauma. 2006 October;61(4):961-8. doi: 10.1097/01.ta.0000195988.57939.9a.

25. Bernstein NR, O'Connell K, Chedekel D. Patterns of burn adjustment. J Burn Care Rehabil. 1992;13(1):4-12. 26. Goyatá SLT, Rossi LA, Dalri MCB. Diagnósticos de enfermagem de familiares de pacientes adultos queimados no período próximo à alta hospitalar. Rev. Latino-Am. Enfermagem. 2006;14(1):102-9.

27. Moi AL, Wentzel-Larsen T, Salemark L, Hanestad BR. Long-term risk factors for impaired burn-specific health and unemployment in patients with thermal injury. Burns. 2007;33(1):37-45.

28. Rossi LA, Camargo C, Santos CMNM, Barruffin RCP, Carvalho EC. A dor da queimadura: terrível para quem sente, estressante para quem cuida. Rev. Latino-Am. Enfermagem. 2000;8(3):18-26.

29. Costa ECFB, Rossi LA. As dimensões do cuidado em uma unidade de queimados: um estudo etnográfico. Rev Esc Enferm USP. 2003;37(3):72-81.

30. Noble J, Gomez M, Fish JS. Quality of life and return to work following electrical burns. Burns. 2006;32(2):15964. doi: $10.1016 /$ j.burns.2005.08.022

31. Butterworth B. Promoting self-care for burn patients. Can Nurse. 1991;87(9):27-30.

32. Whitehead TL. Sexual health promotion of the patient with burns. J Burn Care Rehabil. 1993;14(2):221-6.

33. Cromes GF, Holavanahalli R, Kowalske K, Helm P. Predictors of quality of life as measured by the Burn Specific Health Scale in persons with major burn injury. J Burn Care Rehabil. 2002;23(3):229-34.

34. Pallua N, Kunsebeck HW, Noah EM. Psychosocial adjustments 5 years after burn injury. Burns. 2003;29(2):143-52. doi: 10.1016/S03054179(02)00238-3

35. Salisbury R. Burn rehabilitation: our unanswered challenge. The 1992 presidential address to the American Burn Association. J Burn Care Rehabil. 1992;13(5):495-505.

36. Königová R. Factors influencing survival and quality of life in burns. Acta Chir Plast. 1996;38(4):116-8.

37. Tucker P. Psychosocial problems among adult burn victims. Burns Incl Therm Inj. 1987;13(1):7-14.

38. Anzarut A, Chen M, Shankowsky H, Tredget EE. Quality-of-life and outcome predictors following massive burn injury. Plast Reconstr Surg. 2005 September; 116(3):791-7. doi: 10.1097/01prs.00001176257.225 $83.4 \mathrm{~b}$
39. Esselman PC, Ptacek JT, Kowalske K, Cromes GF, deLateur BJ, Engrav LH. Community integration after burn injuries. J Burn Care Rehabil. 2001;22(3):221-7. 40. Thombs BD, Bresnick MG, Magyar-Russell G. Depression in survivors of burn injury: a systematic review. Gen Hosp Psychiatry. 2006;28(6):494-502. doi: 10.1016/j.genhosppsych.2006.08.010

41. Questad KA, Patterson DR, Boltwood MD, Heimbach DM, Dutcher KA, de Lateur BJ, et al. Relating mental health and physical function at discharge to rehabilitation status at three months post-burn. J Burn Care Rehabil. 1988;9(1):87-9.

42. Bowden ML, Thomson PD, Prasad JK. Factors influencing return to employment after a burn injury. Arch Phys Med Rehabil. 1989;70(10):772-4.

43. Cobb N, Maxwell G, Silverstein P. The relationship of patient stress to burn injury. J Burn Care Rehabil. $1991 ; 12(4): 334-8$.

44. Peota C. Survivor support. Minn Med. 2004;87(3):30-1.

45. Blumenfield $M$, Shoeps $M$. Reintegrating the healed burned adult into society: psychological problems and solutions. Clin Plas Surg. 1992;19(3):599-605.

46. Fukunishi I, Sasaki K, Chishima Y, Anze M, Saijo M. Emotional disturbances in trauma patients during the rehabilitation phase: studies of posttraumatic stress disorder and alexithymia. Gen Hosp Psychiatry. 1996;18(2):121-7.

47. Blalock SJ, Bunker BJ, DeVellis RF. Psychological distress among survivors of burn injury: the role of outcome expectations and perceptions of importance. J Burn Care Rehabil. 1994;15(5):421-7.

48. Fauerbach JA, Heinberg LJ, Lawrence JW, Munster AM, Palombo DA, Richter D, et al. Effect of early body image dissatisfaction on subsequent psychological and physical adjustment after disfiguring injury. Psychosom Med. 2000;62(4):576-82.

49. Willebrand M, WikehultB, Ekselius L. Social desirability, psychological symptoms, and perceived health in burn injured patients. J Nerv Ment Dis. 2005;193(12):820-4. doi: 10.1097/01.nmd.0000188976.84146.c3

50. Patterson DR, Questad KA, Boltwood MD, Covey $\mathrm{MH}$, de Lateur BJ, Dutcher KA, et al. Patient self-reports three months after sustaining a major burn. J Burn Care Rehabil. 1987;8(4):274-9.

51. Helm PA, Walker SC. Return to work after burn injury. J Burn Care Rehabil. 1992;13(1):53-7.

52. Druery $M$, Brown TL, Muller M. Long term functional outcomes and quality of life following severe burn injury. Burns. 2005;31(6):692-5. doi: 10.1016/j. burns.2005.03.001 
53. Sliwa JA, Heinemann A, Semik P. Inpatient rehabilitation following burn injury: patient demographics and functional outcomes. Arch Phys Med Rehabil. 2005; 86(10):1920-3. doi: 10.1016/j.apmr.2005.04.024

54. Doctor JN, Patterson DR, Mann R. The 1997 Clinical Research Award. Health outcome for burn survivors. J Burn Care Rehabil. 1997;18(6):490-5.

55. Jonsson CE, Schuldt K, Linder J, Bjornhagen V, Ekholm J. Rehabilitative, psychiatric, functional and aesthetic problems in patients treated for burn injuries--a preliminary follow-up study. Acta Chir Plast. 1997;39(1):3-8.

56. Klinge $K$, Chamberlain DJ, Redden M, King L. Psychological adjustments made by postburn injury patients: an integrative literature review. J Adv Nurs. 2009 Nov;65(11):2274-92.

57. Dyster-Aas J, Willebrand M, Wikehult B, Gerdin B, Ekselius L. Major depression and posttraumatic stress disorder symptoms following severe burn injury in relation to lifetime psychiatric morbidity. J Trauma. 2008;64(5):1349-56.

58. Patterson DR, Finch CP, Wiechman SA, Bonsack R, Gibran N, Heimbach D. Premorbid Mental Health Status of Adult Burn Patients: Comparison with a normative sample. J Burn Care Rehabil. 2003;24(5):347-50.

59. Horowitz M, Wilner N, Alvarez W. Impact of Event Scale: a measure of Subjective Stress. Psychosom Med. 1979;41(3):209-18.

60. Silva LF, Guedes MVC, Moreira RP, Souza ACC. Doença crônica: o enfrentamento pela família. Acta Paul Enferm. 2002;15(1):40-7.

61. Connor-Ballard PA. Understanding and Managing Burn Pain: part 1. Pain after burn injury is preventable, and nurses are central to achieving that goal. AJN. 2009;109(4):48-56. 